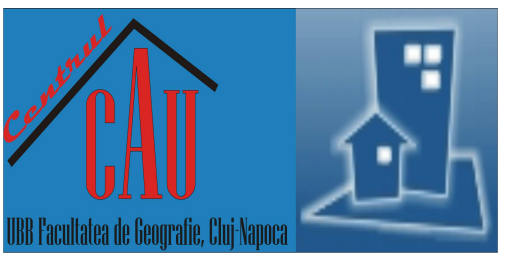

\title{
"The Village as a Place of...". Anchoring the Territorial Identity of the Countryside. Examples from Poland
}

\author{
Paulina TOBIASZ-LIS ${ }^{*}$, Marcin WÓJCIK1 \\ * Corresponding author \\ 1 University of Lodz, Faculty of Geographical Sciences, Department of Regional and Social Geography, Lodz, POLAND \\ $\triangle$ paulina.tobiasz@geo.uni.lodz.pl (i) https://orcid.org/oooo-ooo2-2739-1406 \\ $\triangle$ marcin.wojcik@geo.uni.lodz.pl iㅣ https://orcid.org/oooo-ooo2-5236-5381 \\ DOI: 10.24193/JSSPSI.2021.7.05 \\ https://doi.org/10.24193/JSSPSI.2021.7.05
}

K e y w o r d s: rurality, representations, narratives, place attachment, territorial identity, Poland

\begin{abstract}
A B S T RACT
The aim of this paper is to discuss how inhabitants of selected villages in Poland perceive their living space, what meanings they assign to it and what is important for them in their nearest neighbourhoods. The presented research is set within the cultural approach in rural geography, in which the notion of experienced and imagined rural spaces is central. We answer the question whether there are any general patterns referring to the process of transforming the space into a "place", defined by the individual understanding of rurality, strengthening local identity and place attachment. Research was based on guided individual in-depth interviews in order to extract inhabitants' narratives about the selected villages. Individual stories collected along the study reveal an image of the countryside as significant, often beloved, and close place, marked with a special meaning and value for interviewees, shaping their sense of self and place attachment. The interpretation of these narratives is structured into four categories of "anchors" and "magnets" focused on: 1) the village as a place of generational continuity, attachment, and rootedness; 2) the village as a place of cultivating local customs and remembrance of important historical events; 3) the village as an important, close, and familiar place; 4) the village as an attractive place to live and referred to the person-process-place framework of place attachment.
\end{abstract}

\section{INTRODUCTION}

This paper aims to discuss the spatial imagery of rural settlements, extracted from inhabitants' narratives about their villages. The presented stories show the countryside as significant, often beloved, and close place, marked with a special meaning and value for the interviewees.

The notion of the "narrative" ("story") has gained much interest and important position in social sciences, including human geography. It is used with respect to the theoretical framework development as well as in applied research. The analysis focuses on the language, as a form of social practice. The respective methodology allows to investigate the socially produced texts and the processes of communication (Tomanek, 2008; Rembowska, 2011).

The narrative, as the concept of description and interpretation of reality, grows out of the humanistic, person-related approaches, where most of the attention is focused on people and their relationship with the environment. They might be considered as 
examples of representations of places which gained a strong interest in human geography since the cultural turn of the 1980 s, and more generally with the poststructuralist turn in social sciences (see further: Banini and Ilovan, 2021b). The narratives, as definite points of view, constitute an exceptionally valuable material for the study of perceptions and imaging, also regarding space, concerning people and communities (cf. TobiaszLis, Jeziorska-Biel and Wójcik, 2020). Of key importance, here is also the reference to the value of "places" as the "experienced spaces", meaningful structures, regarding the events and the actions, and linked with the search for the holistic sense of humanenvironment relations (Rembowska, 2011). Stories, including the ones that are focused on "places", are the way to uncover the structure of cognition and comprehension of the people's living spaces. One can point out that owing to the story, "the reality - the social space - is no longer conceived as external and independent of the people who live in it or explore it; it is the world of human experience, constituted by this experience" (Rembowska, 2011, p. 75).

From the point of view of the story, its subject in a definite space identified by individuals, or rather by social groups, having taken roots in that "place". The "place" is the substrate of human existence, and the main vein of the story about it refers to the consideration of time, in which the relations between people, forming a community, featuring definite cultural qualities, customs and institutions, developed and have been reproduced (Soja, 1999). From such a point of view, the narrative concerns the process of creation and rendering of the social space, that is - the multiple senses of existence, conditioning of the social practices, maintenance, and establishment of the social life institutions, all this within definite physical frames, determined by the nature and the forms of development of the "places" (Rembowska, 2011).

The stories of "places" presented in this paper show people, their lives, actions, and ideas, in concrete local settings. These descriptions of villages as "places" are people's individual discussions with the experienced environment, both emphatic and critical. The persistent motif, a kind of "thread", weaving together all the essential elements, is the reference to the dynamics of the "place", its extraordinary and unprecedented character. All possible ways to reconstruct "rurality", shown in the studied stories, present the simplicity of the idea, as well as the mechanisms and effects of transforming "spaces" into "places". The analysis of the content of the narratives on the villages as "places" makes it possible to emphasize that the specificity of rural life is expressed in the ways people inhabit and shape their land, which, owing to their memory, concepts, and efforts, turns space into "places", soaked with the traces, left by the successive generations of inhabitants.

\section{METHODOLOGY}

Various concepts of space impact the methodology of contemporary human geography and result in several interpretations: as a territory - from a perspective of social and political organization of space, as a place - from a perspective of spatial evaluation, as a landscape - indicating a visual aspect of space (Harvey 1989; Gregory 1994; Soja 1996). In approaches derived from the "reflexive turn" in social sciences, adopted in this paper, it is assumed as possible to understand space in the form in which it is perceived by its users, who constantly construct and reconstruct their spatial knowledge based on everyday spatial experiences, which leads towards place attachment (Soja 1999; Sławecki 2012; Tobiasz-Lis et al., 2019).

The research on the social representations of villages, reflected in the individual stories of their inhabitants, was carried out using the technique of individual in-depth interview (IDI), with a standardized list of issues to be discussed with each interviewee. In this case, the instructions were organized into three main thematic blocks: 1) interviewee's biography in relation to the village and attitude towards it; 2) the interviewee's attitude to important places in the village; 3) the interviewee's social activity. Questions aimed to stimulate interviewees to construct a story, as a kind of stimulus directed at the storyteller. This is favoured by the expressive and biographical, but also narrative nature of the individual in-depth interview, similar to everyday conversation and having an important social function - to confirm socio-spatial relations within the community.

On the theoretical level, to explain reasons of using IDIs in this research, the reference is made to the narrative concept in human geography, assuming that space is not only experienced through language, but also constructed through language. Human mind captures reality in the form of descriptions, interprets it as specific stories and organizes individual experiences in the form of meaningful narratives. On the narrative, and on the narrative framework depends how individuals experience themselves and the world, and which aspects of reality will be noticed, named, and expressed (Neisser, 1967). This sense fits in with the humanistic interpretation of space, which, in the process of assigning meanings, becomes a "place".

In total, eleven individual in-depth interviews were conducted with people living in eleven villages Piwoda, Księże Pole, Miłoszyce, Czerwona, Holendry Baranowskie, Długowola, Zielnowo, Słowino, Pacew, Nowoskłoniec, Niezabyszewo - as a part of the broader, systematic research within the project on Spatial Representations of Rural Settlements in Poland (Wójcik, 2020; Wójcik, Tobiasz-Lis and Jeziorska-Biel, 2021), undertaken between May and September 2017, in 22 settlements (Fig. 1). 


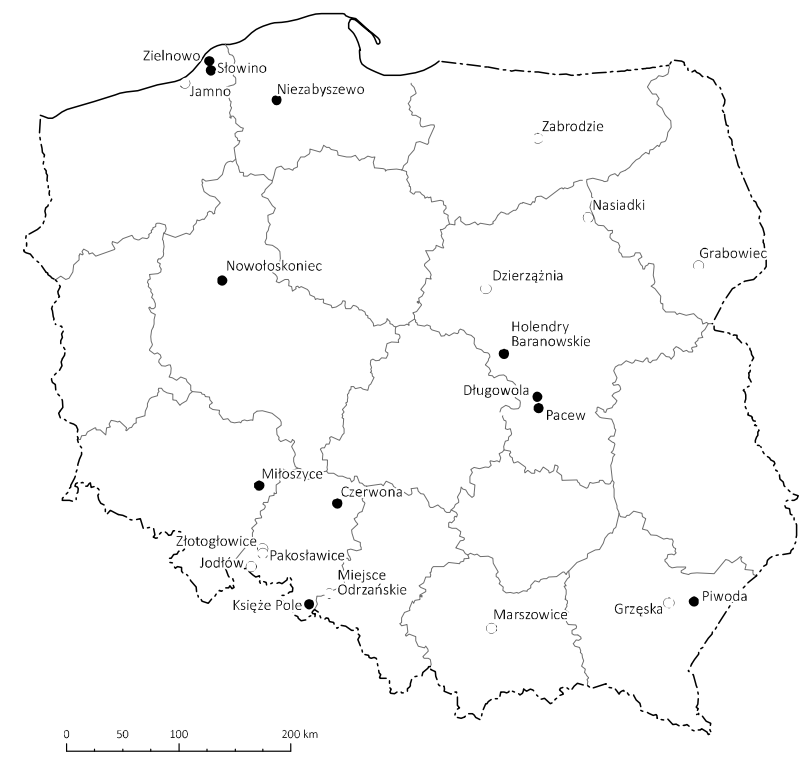

Fig. 1. Spatial distribution of the 22 villages under study (Note: Black signatures represent the 11 villages where IDIs were conducted).

The key for selecting our case studies out of nearly 200 settlements listed in Atlas Historyczny Wsi w Polsce [Historical Atlas of Villages in Poland] (Szulc, 2002), was the presence of significant cultural heritage in terms of well preserved and legible historical rural spatial patterns developed in different cultural regions of Poland. The chosen villages were located in predominantly rural areas, peripheral to regional centres, having strong agricultural functions and usually undergoing significant depopulation and ageing of remaining population.

Participants at the individual in-depth interviews emerged from the total number of 189 inhabitants of all 22 villages, who took part in semistructured, questionnaire interviews. After this phase, only people willing to share their life stories, applied for participating in individual in-depth interviews. Although when planning the first phase, a strong attention was paid to maintain proportions of the population sample according to basic demographic and social characteristics of the chosen communities, a nonrandom choice of interviewees in the second phase conducted with the use of individual in-depth interviews should be considered as framing and somewhat limiting its results. As to the gender balance of interviewees - there were seven women and four men. All participants were over 40 and have been living for all their lives in the analysed villages or moved from a very near neighbourhood after getting married (a frequent situation especially among interviewed women). It may be argued that a weakness of our work is to follow stories of only one person in each locality, who does not represent the general point of view of the entire community, but we consider this as a reference point to future comparative studies guided by narratives of representatives of the youth and of the newcomers, to bring a more in-depth picture of the contemporary countryside.

The recorded and transcribed interviews were interpreted according to G. Rose's (2007) "Discourse analysis I: text, intertextuality and context”. We focused on the content of individual stories and incorporated qualitative analysis, asking questions such as: What are the key issues (e.g. key words or images) reflected by the stories told by the villagers? How are these given specific meanings? What are the connections between words and images - the landscape of particular villages and the interviewees' nearest neighbourhoods? Photographic documentation was a very important element of our study. The photographs presented in this paper aim at illustrating stories revealed along individual in-depth interviews (Fig. 2-4).

Results were then interpreted from the perspective of the three-dimensional person-processplace framework (cf. Scannell and Gifford, 2010), widely discussed in literature as synthesizing various definitions of place attachment regarding various aspects, forms, scales, and factors of human interaction with places.

\section{RESULTS AND DISCUSSION}

Rurality, as revealed in narratives through recurring words and images, is constructed as idyllic, and belonging integrates three key issues of the rural lifestyle: "home", "family" and "nature". Home is represented as both objective (perceived) and imaginative, a site and a set of emotions and meanings, as people's self-sense is related to and produced through lived and imagined experiences of home and home-making practices are much emphasized (cf. Blunt and Dowlings, 2006).

The second issue uncovered by the interviewees' stories that is closely related to home is "family". The rural home is filled with beliefs, values and meanings that reflect and reproduce ideas about the multigenerational rural family, traditional in terms of gender relations and belonging to the community. Conditions for bringing up children are often underlined and the key arguments here are safety, as the countryside is situated away from the dangers of the city, and the well-being due to the value of belonging to a community (cf. Valentine, 1997).

The third issue focused on "nature" and is emerging from interviewees' stories as related to many aspects: "upbringing children close to nature, in a safe environment" in addition to home and family life described above. Also "food", as local, traditional, and produced for oneself is often underlined. Following issues of agricultural production, interviewees pointed out landscape changes in terms of seasons, coupled with food, cooking, but also with home-making (e.g. growing 
flowers). Thus, the countryside is represented as a space of nature and the natural, attractive for domesticity and family life.

Stories present particular villages as places of special significance and value. They are often the first and the only places of their residence, which additionally enhances territorial identity and place attachment. Moreover, stories often reveal moral
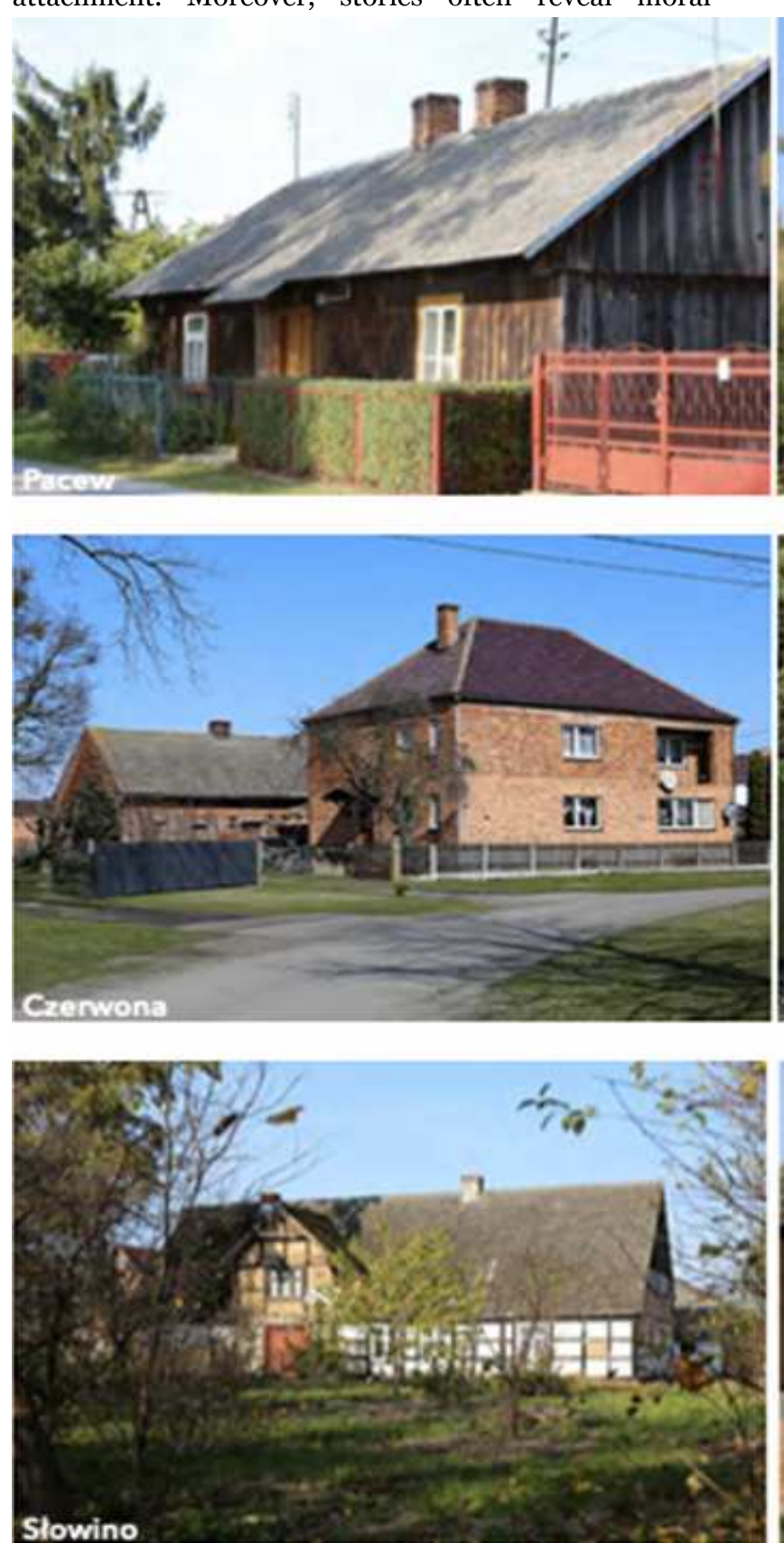

Fig. 2. "Home" - the most important place - the centre of the interviewees' everyday lives.

The perception of interviewees' place of residence, revealed by individual narratives, could be divided into four basic categories:

a). The village as a place of identity, generational continuity, attachment and rootedness: "For as long as I can remember, my whole family has lived here, it is the only place I know on earth, mine, it instructions, religious allegories and other forms of local customs or anecdotes repeated for generations. In this way, the body of local knowledge is created, specific to a certain community. According to the interviewees, their living space is signified by places that are important and familiar to them. Specific values and meanings of these places are usually well recognizable and understood within the whole community.
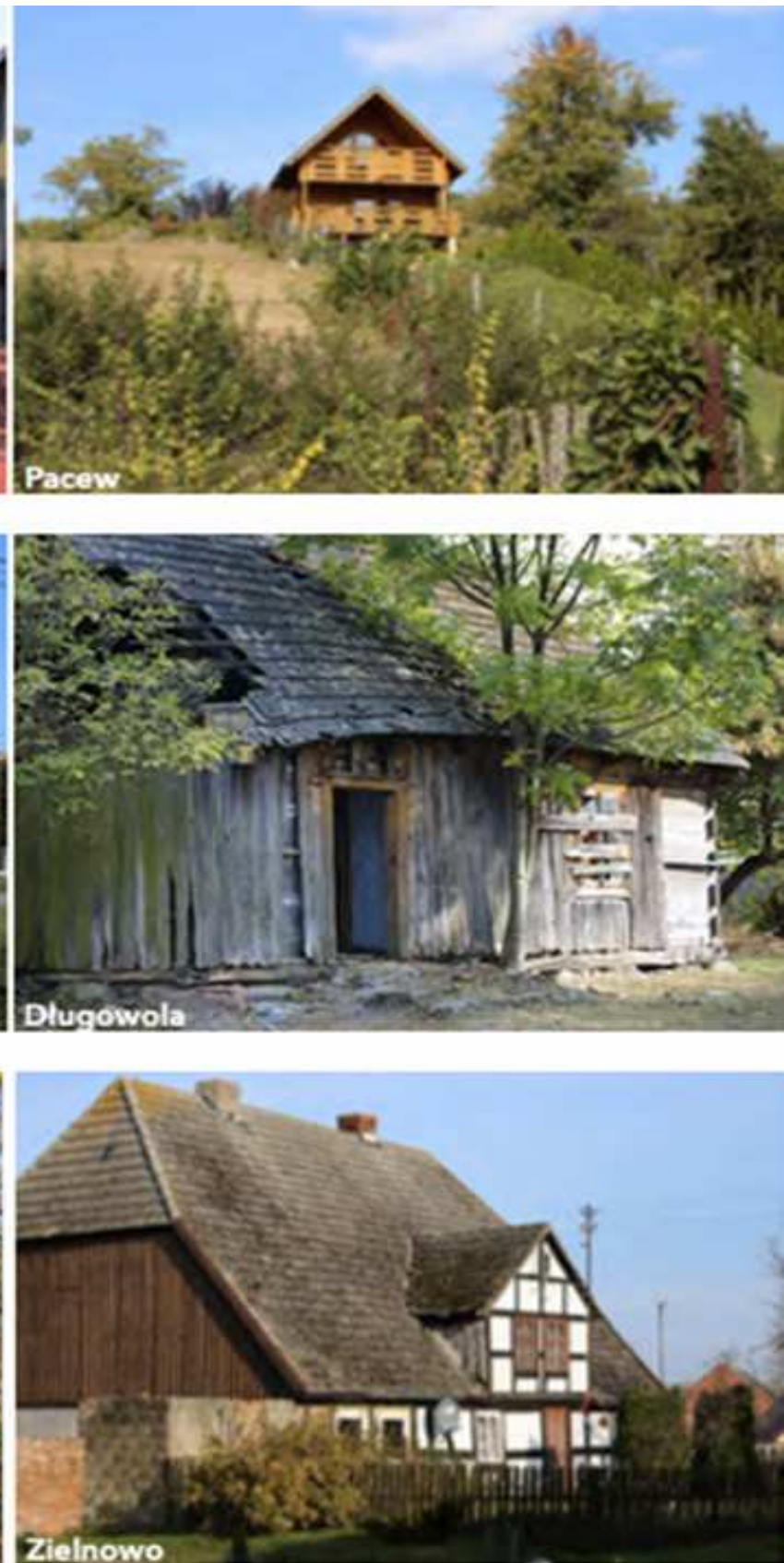

has always been mine" (Długowola, M.); "I feel that I have grown roots here. They respect me here; for example, when they built a church, I wrote various speeches ... people worked here in my backyard, so ... they have known me for a long time, so that they know who I am and, somehow, I have earned myself respect from people. I don't think I could live anywhere else. 


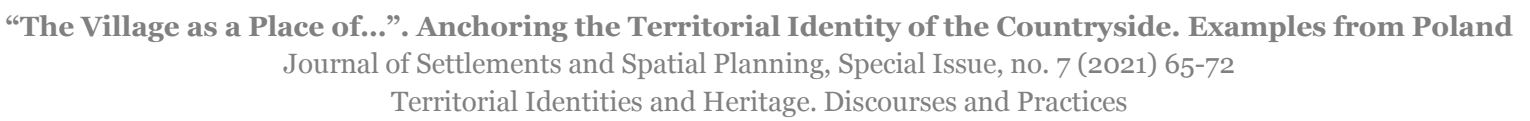

This place is my family home. I know every path here. I gave birth to my children here. I live here. I have set up my house here" (Piwoda, F.).

b). The village as a place of cultivating local customs and a place of remembrance of important historical events: "As far as possible, we try to cultivate traditions and remember how our ancestors lived" (Holendry Baranowskie, M.); "There was a branch of the Nazi-German concentration camp in Miłoszyce. The former Jelcz factory, called Krupa, produced armaments for the Germans during the war. Many people died in the camp. There is a collective grave in Miłoszyce commemorating those killed in the camp" (Miłoszyce, M.).

c). The village as an important, close and familiar place: "My house is the most important place for me. I bought it with my husband after we got

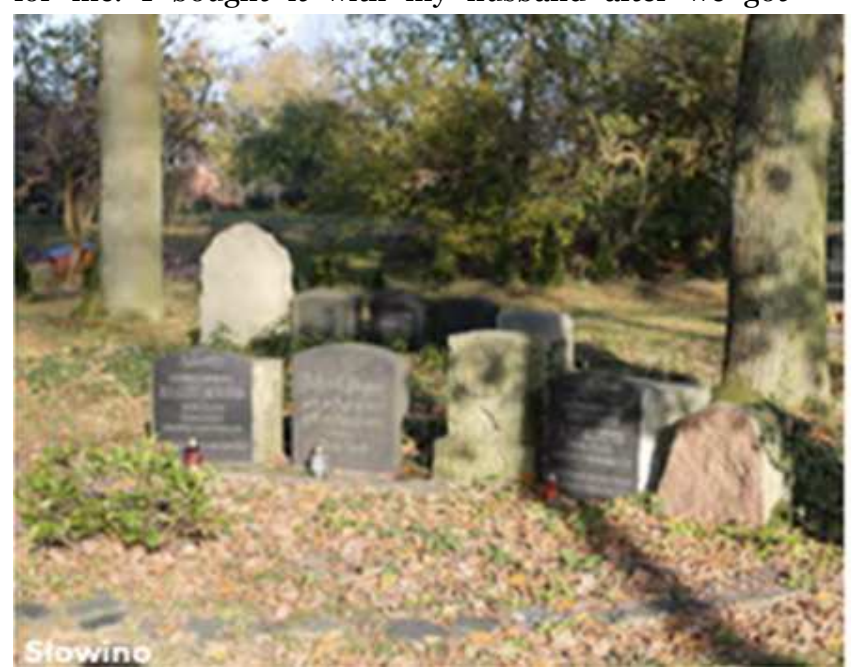

Fig. 3. The village as the place of cultivating local customs and a place of remembrance of important historical events.

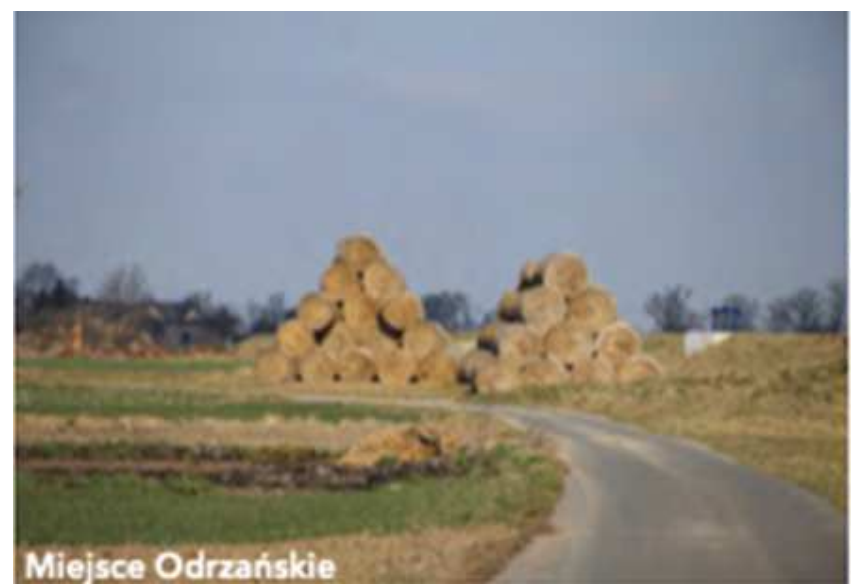

Fig. 4. The village as attractive place to live.

As presented above, our qualitative analysis of individual in-depth interviews focused on the redefinition of rurality and the meaning of specific villages as people's living space, according to the key issues revealed by participants' narratives. In the last research phase, we compared them with the personprocess-place framework of place attachment which is recognized as summarizing and generalizing different married. It is over 200 years old. When we started to renovate the attic, we discovered the date of its construction. The year 1795 was scratched on the wall, so we assume that it was built then. This house is an important place for me because I've lived here almost all my life with my husband. Our children grew up here, and now our grandchildren live with us as well. I think that our home is not perceived by others as something special. It is an ordinary house, like many in the village, but it is important to me and my family" (Pacew, F.);

d). The village as an attractive place to live in: "Our village is peaceful and quiet. It is safe. People are very helpful and kind. They help each other if necessary. There is no noise of passing cars. There is no factory farming, so there is no unpleasant smell. We live well here" (Czerwona, F.).
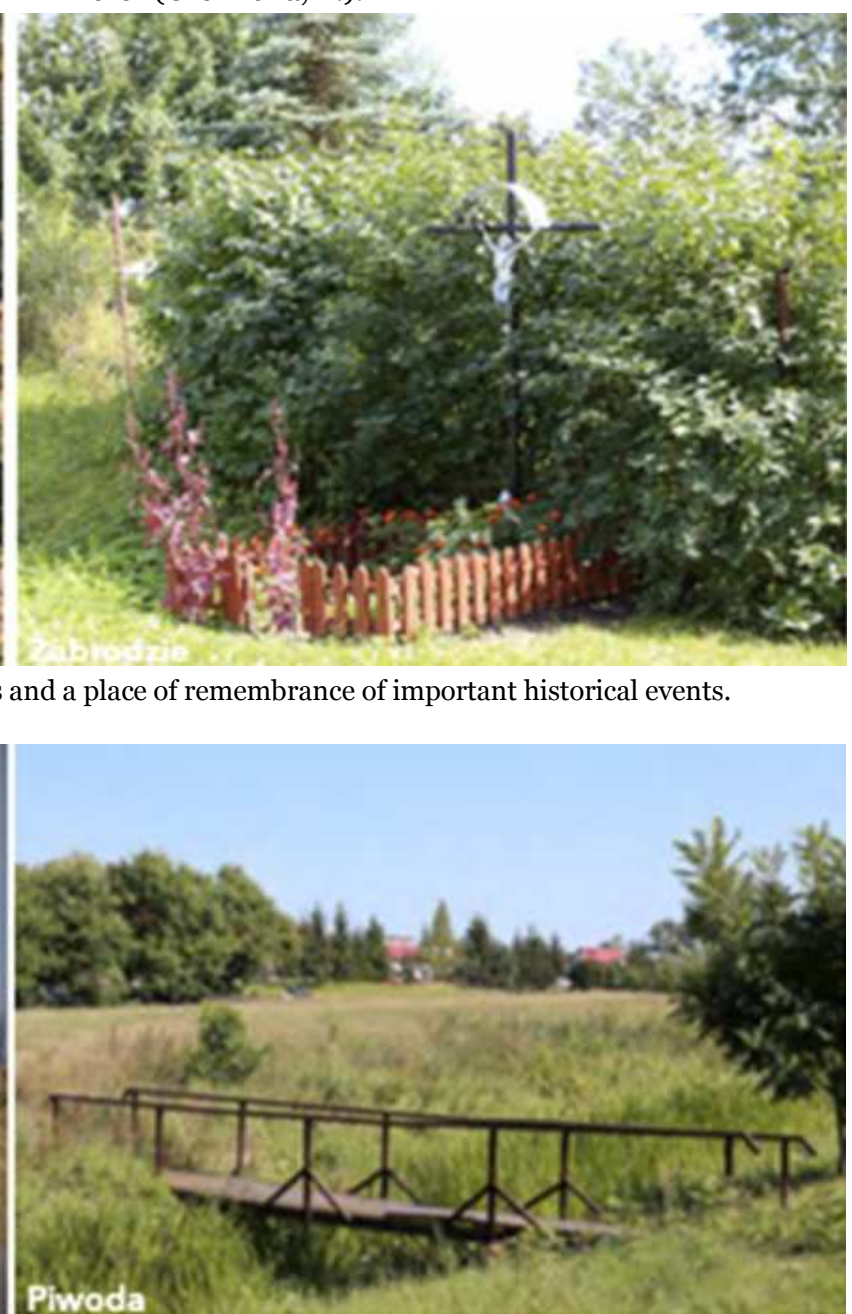

theories and research in practice (Junot, Paquet and Fenouillet, 2018; Lewicka, 2011; Halpenny, 2010; Scannell and Gifford, 2010).

It covers three dimensions of the relation between individuals and their places: cognitive defined as perceptions of formal aspects of places, behavioural - focused on functional context and possible activities to be undertaken in place and 
affective informed by specific values and beliefs that people attach to places. Additionally, the personprocess-place framework considers both the individual and collective perspective of human interaction with places, referring to perceptions, activities and meanings of places revealed by individuals, groups of people or whole communities. This approach corresponds well to the classic works by Y. F. Tuan $(1974,1977)$ and E. Relph (1976), who believed that the concept of place is attributed to humankind, and without people it is only a geographical location. They have described "topophilia", meaning love of place, and "sense of place," which is often defined similarly to place attachment.

Comparing individual stories revealed by rural residents along individual in-depth interviews with the place attachment defined by the person-process-place framework, it might be stated that all dimensions of these specific bonds between the village and its residents are strengthened in all investigated locations (Table 1).

Table 1. Narratives reflected in the person-processplace framework of place attachment.

\begin{tabular}{|c|c|c|}
\hline \multicolumn{3}{|c|}{$\begin{array}{l}\text { The village as the place of... } \\
\text { Person-Process-Place framework for place attachment }\end{array}$} \\
\hline \multirow{2}{*}{$\begin{array}{l}\text { Person } \\
\text { who? }\end{array}$} & Individual & $\begin{array}{l}\text {... identity and generational } \\
\text { continuity } \\
\text { personal experiences, family relations }\end{array}$ \\
\hline & Collective & $\begin{array}{l}\text {... remembrance of important } \\
\text { events } \\
\text { shared experiences of all inhabitants }\end{array}$ \\
\hline \multirow{3}{*}{$\begin{array}{l}\text { Process } \\
\text { how? }\end{array}$} & Cognitive & $\begin{array}{l}\text {... as a close and familiar place } \\
\text { knowledge, memories, beliefs that } \\
\text { make place meaningful }\end{array}$ \\
\hline & Behavioural & $\begin{array}{l}\text {... cultivating local traditions } \\
\text { place attachment expressed through } \\
\text { particular behaviours }\end{array}$ \\
\hline & Affective & $\begin{array}{l}\text {... happy to live here, love the } \\
\text { place } \\
\text { emotional component of place } \\
\text { attachment }\end{array}$ \\
\hline \multirow{2}{*}{$\begin{array}{l}\text { Place } \\
\text { where? }\end{array}$} & Physical & $\begin{array}{l}\text {... an attractive place to live } \\
\text { place attachment stems form aesthetic } \\
\text { and landscape values }\end{array}$ \\
\hline & Social & $\begin{array}{l}\text {... attachment and rootedness } \\
\text { place attachment stems from social } \\
\text { ties }\end{array}$ \\
\hline
\end{tabular}

As to the dimension of the person, at the individual level, interviewees mentioned their memories of childhood, youth, important events that involved them in person. Past experiences, especially the Second World War shaping particular places and the social ties, were often mentioned as shared by whole communities. The three psychological aspects of place attachment which are frequently underlined in various theoretical and practical definitions are affection, cognition, and behaviour. Affection is thought to be central in the person-place relation, and indeed positive emotions about villages appear in all eleven conducted interviews. People are proud of their villages, happy to live there and to be a part of these places. They identify themselves with the territory, the community and local customs, which are all examples of place attachment as cognition. The third aspect of the psychological process dimension of place attachment is focused on behaviour, underpinning attachment with joint socio-cultural activities engaging members of the community. In villages under study, people mentioned important religious events, local feasts, and participation in local planning. Perhaps the most critical dimension of place attachment is the place itself. The notion of "the community of place" is regarded to be very relevant here because it describes social bonds rooted in place that support social interactions. However, as it has been presented above, investigated villages might be interpreted as places in various dimensions and multiply a sense of belonging.

As revealed by our research, the narrative perspective allows the researcher to reach what usually eludes experimental studies - subjective and unique meanings, to discover the way in which people construct their individual relationship with the world (Banini and Ilovan, 2021a; Peritz and Carr, 2021; Wójcik, 2017). The narrative is a way of people's understanding of reality that is revealed in remembering the past as a series of specific stories and envisioning the future in the form of possible scenarios. It is not that stories "happen" to people in life, it is rather the specific structure of their knowledge of the world that determines the narrative way of seeing reality. Stories, as specific points of view and beliefs, are a valuable material for research on territorial identities and place attachment (Lewicka, 2012).

A village as a "place" is, at the same time, a living space and an arena for everyday events and experiences. The habitation sphere connects all rural ways of life (Wójcik, 2012). The idea of "living in" has a timeless dimension and, regardless of changing conditions, especially modern technological progress, it is reflected in the process of starting a family, building a house, and developing a nearby space according to one's own rules and beliefs.

\section{CONCLUSIONS}

The presented research, conducted with the use of qualitative methodology, the narrative approach, allows for uncovering local meanings and for the interpretation of a village as a "place", an original construct - simultaneous process and effect of the multigenerational relationship of rural residents with their nearest neighbourhood. Paying attention to the individual life stories of rural residents, intertwined in specific geographical conditions - related to both nature and culture, makes a highly tempting and interesting perspective to describe and explain spaces 


\section{“The Village as a Place of...". Anchoring the Territorial Identity of the Countryside. Examples from Poland Journal of Settlements and Spatial Planning, Special Issue, no. 7 (2021) 65-72 Territorial Identities and Heritage. Discourses and Practices}

becoming places in the process of personal experiences, identification, and territorial attachment.

The practical dimension of studying individual perceptions of rural settlements is largely related to the planning of the countryside, especially under conditions of rapid changes towards multifunctional rural areas. Bearing this in mind, we must stress that the results presented in this article show the perspective of remaining and nostalgic, older inhabitants of the villages under study. In further research, it would be beneficial to interview people representing two other groups composing contemporary rural communities in Poland: the youth, yet related to old settlers, and the newcomers, who choose rural life in order to reveal a more in-depth picture, reflecting presumably three different, maybe even conflicting perceptions of rurality. Then, narratives may prove to be extremely helpful, especially at the process of identifying problems related to weakening of social relations, or to the visibility and clarity of elements of rural space, its cultural heritage, which are an expression of the dynamic transformations of the contemporary world.

We obtained information on the rural settlements as spaces of everyday live and their quality as perceived by people to reflect in places important both from the perspective of individual experiences and the experiences of entire local communities. This article endeavours to contribute to the discursive constructions of contemporary rurality. We argue that it is crucial to recognize social representations in the process of interpreting values framing rural life.

\section{ACKNOWLEDGEMENTS}

The presented research is a part of the National Science Centre funding scheme, "Spatial representations of rural settlements in Poland", conducted by the Department of Regional and Social Geography, University of Lodz, since the beginning of 2015 to the end of 2019.

\section{REFERENCES}

Banini T., Ilovan O.-R. (2021a), Conclusions: towards a new agenda for place/territorial identity research. In: Banini T., Ilovan O.-R. (eds.), Representing Place and Territorial Identities in Europe. GeoJournal Library, vol. 127. Springer, Cham, 251-265. DOI: https://doi.org/10.1007/978-3-030-66766-5_17.

Banini T., Ilovan O.-R. (2021b), Introduction: dealing with territorial/place identity representations. In: Banini T., Ilovan O.-R. (eds.), Representing Place and Territorial Identities in Europe. GeoJournal Library, vol. 127. Springer, Cham, 1-19. DOI: https://doi.org/10.1007/978-3-030-66766-5_1.

Beckley T. S. (2003), The relative importance of socio-cultural and ecological factors in attachment to place. General Technical Report PNW-GTR-566. In: Kruger L. E. (ed.), Understanding community - forest relations. Portland, Oregon, 105-126.

Blunt A., Dowling R. (2006), Home. London and New York: Routledge. ISBN: 978-04-1533-275-0.

Gregory D. (1994), Geographical Imaginations. Blackwell, Oxford. ISBN: 978-06-3118-331-o.

Halpenny E. A. (2010), Pro-environmental behaviors and park visitors: The effect of place attachment. Journal of Environmental Psychology, 30, 409-421, DOI: 10.1016/j.jenvp.2010.04.006.

Harvey D. (1989), The Condition of Postmodernity: An Enquiry into the Origins of Cultural Change. Blackwell, Oxford. ISBN 978-0-631-16294-0.

Junot A., Paquet Y., Fenouillet F. (2018), Place attachment influence on human well-being and general pro-environmental behaviors. Journal of Theoretical Social Psychology, 2, 49-57, DOI: 10.1002/jts5.18.

Lewicka M. (2011), Place attachment: How far have we come in the last 40 years. Journal of Environmental Psychology, 31, 207-230, DOI: 10.1016/j.jenvp.2010.10.001.

Lewicka M. (2012), Psychologia miejsca. [Psychology of place], Wydawnictwo Scholar, Warszawa. ISBN 97883-7378-476-7.

Neisser U. (1967), Cognitive Psychology. Englewood Cliffs, Prentice-Hall. ISBN: 978-01-3139-667-8.

Periz A., Carr L. M. (2021), Iron men on wooden boats: connection and isolation between local culture and the sea in Coastal Donegal. In: Banini T., Ilovan O.R. (eds.), Representing Place and Territorial Identities in Europe. GeoJournal Library, vol. 127. Springer, Cham, 235-249. DOI: https://doi.org/10.1007/978-3030-66766-5_16.

Relph E. (1976), Place and Placelessness. Pion, London. ISBN: 978-18-4519-317-1.

Rembowska K. (2011), Geografia regionalna jako opowieść [Regional geography as a story]. In: Maik W. (ed.), Rembowska K., Suliborski A. (eds.), Geografia regionalna - scalenie i synteza wiedzy geograficznej, Podstawowe idee i koncepcje $\mathrm{w}$ geografii [Regional geography - the synthesis of geographical knowledge. Main theories and concepts in geography]. Wydawnictwo Uniwersytetu Łódzkiego, Łódź, 73-80.

Rose G. (2007), Visual Methodologies. An Introduction to the Interpretation of Visual Materials, $2^{\text {nd }}$ edition. London, Sage. ISBN: 978-1-4129-2191-6.

Scannell L., Gifford R. (2010), Defining place attachment: A tripartite organizing framework. Journal of Environmental Psychology, 30, 1-10. DOI: 10.1016/j.jenvp.2009.09.006.

Sławecki B. (2012), Znaczenie paradygmatów w badaniach jakościowych [The meaning of paradigms in qualitative research]. In: Jamielniak D. (ed.), Badania jakościowe. Podejścia i teorie [Qualitative research. Theoretical approach]. Wydawnictwo Naukowe PWN, Warszawa, 57-87. 
Soja E. (1996), Thirdspace: Journeys to Los Angeles and Other Real and Imagined Places, Verso, London. ISBN 978-15-5786-675-2.

Soja E. (1999), Thirdspace: Expending the Scope of the Geographical Imagination. In: Massey D. B., Allen J., Sarre P. (eds.), Human Geography Today. Polity Press, Blackwell Publishers, 260-278.

Szulc H. (2002), Atlas Historyczny Wsi w Polsce [Historical Atlas of Villages in Poland]. Polska Akademia Nauk, Instytut Geografii i Przestrzennego Zagospodarowania, Warszawa. ISBN: 83-87954-90-X.

Tobiasz-Lis P., Wójcik M., Dmochowska-Dudek K., Jeziorska-Biel P. (2019), Thematic village as the new anchor for local development: a lesson from Masłomecz, Poland. Europa Regional, 26(2), 29-42.

Tobiasz-Lis P., Jeziorska-Biel P. Wójcik M. (2020), Wyobrażenia przestrzenne jako forma reprezentacji wsi. [Spatial images as representations of the countryside]. In: Wójcik M. (ed.), Reprezentacje przestrzenne wsi w Polsce [Spatial representations of rural settlements in Poland]. Wydawnictwo Uniwersytetu Łódzkiego, Łódź, 61-84.

Tomanek P. (2008), O swoistości socjologicznej analizy dyskursu. [On the specificity of sociological discourse analysis]. In: Horolets A. (ed.), Analiza dyskursu w socjologii i dla socjologii [Discourse Analysis in and for Sociology]. Wydawnictwo Adam Marszałek, Toruń, 30-44.
Tuan Y.-F. (1974), Space and place: Humanistic perspective. Progress in Geography, 6, 233-246.

Tuan Y. F. (1977), Space and Place: The Perspective of Experience. University of Minnesota Press, Minneapolis, ISBN: 978-08-1660-884-3.

Valentine G. (1997), A safe place to grow up? Parenting, perceptions of children's safety and the rural idyll. Journal of Rural Studies, 13(20), 137-148. DOI: 10.1016/So743-0167(97)83094-X.

Wójcik M. (2012), Geografia wsi w Polsce. Studium zmiany podstaw teoretyczno-metodologicznych [Rural Geography in Poland. A study of changes in theoretical and methodological foundations]. Wydawnictwo Uniwersytetu Łódzkiego, Łódź. ISBN 978-83-7525-657-4. Wójcik M. (2017), W kierunku "miejsca". Budzenie uśpionego potencjału wsi [Toward "place". Awakening the potential of the countryside]. Folia Geographica SocioOeconomica, 28, 5-16. DOI: 10.18778/1508-1117.28.01.

Wójcik M. (ed.) (2020), Reprezentacje przestrzenne wsi w Polsce [Spatial representations of rural settlements in Poland]. Wydawnictwo Uniwersytetu Łódzkiego, Łódź. ISBN 978-83-8220-242-7.

Wójcik M., Tobiasz-Lis P., Jeziorska-Biel P., (2021), Spatial imaginations as a form of rural representation. Lessons from Poland. In: Banini T., Ilovan O.-R. (eds.), Representing Place and Territorial Identities in Europe. GeoJournal Library 127, Springer, Cham, 219-233. DOI: 10.1007/978-3-030-66766-5_15. 